\title{
Pengembangan E-UKBM dengan Aplikasi Kvisoft Flipbook Maker dalam Pembelajaran Fisika untuk Meningkatkan Kemampuan Problem Solving Peserta Didik
}

\author{
Gilang Pratiwi ${ }^{1 *}$, Raden Wakhid Akhdinirwanto ${ }^{2}$, dan Nurhidayati ${ }^{3}$ \\ 1,2,3 Universitas Muhammadiyah Purworejo \\ JIn. K.H.A. Dahlan No. 3 Purworejo \\ *E-mail: pratiwigilang89@gmail.com
}

\begin{abstract}
Abstrak
Elektronik Unit Kegiatan Belajar Mandiri (E-UKBM) satuan pelajaran terkecil yang disusun secara berurutan dari yang mudah sampai ke yang sukar berbasis e-learning menggunakan aplikasi kvisoft flipbook maker sebagai pengembangan bahan ajar melalui media pembelajaran interaktif yang bertujuan untuk meningkatkan problem solving peserta didik. E-UKBM mempunyai karakteristik perangkat pembelajaran untuk mencapai kompetensi pengetahuan dan keterampilan pada pembelajaran dengan menggunakan Sistem Kredit Semester (SKS). Tujuan digunakan E-UKBM untuk meningkatkan kemampuan problem solving peserta didik. Jenis penelitan ini adalah pengembangan hasil dari model desain penelitian Plomp yaitu (1) Preliminary Investigation, (2) Design, (3) Realization/Contruction, (4) Test, Evaluation, and Revision, (5) Implementation. Subjek penelitian ini adalah peserta didik X MIA 3 SMA N 1 Purworejo. Analisis data dilakukan dengan uji validitas dan uji reliabilitas, uji kemampuan problem solving menggunakan pre-test dan post-test. Hasil penelitian ini diperoleh bahwa E-UKBM valid, praktis, dan efektif sehingga layak untuk meningkatkan kemampuan problem solving peserta didik.
\end{abstract}

Kata kunci: E-UKBM, Kemampuan Problem Solving, Kvisoft Flipbook Maker

\begin{abstract}
The Self-Study Activity Unit Electronic (E-UKBM) is a small learning unit that orderly arranged from easy to difficult level based on e-learning using kvisoft flipbook maker application as the development of teaching material through interactive teaching media to improve students problem solving skill. E-UKBM has the characteristic of learning tool to achieve competency of knowledge and skill on teaching process using Sistem Kredit Semester (SKS). The aim of the use of E-UKBM is to improve students problem solving ability. This type of research develops the result of Plomp's research design model, (1) Preliminary Investigation, (2) Design, (3) Realization/Contruction, (4) Tes, Evaluation, and Revision, (5) Implementation. The sample of this research is students of X MIA 3 SMA N 1 Purworejo. This data analysis was done by using the validity and reliability test, the problem solving ability test using the pre-test and post-test. The result of this study indicate that E-UKBM is valid, practical, and effective so that it is feasible to improve students problem solving ability.
\end{abstract}

Keywords: E-UKBM, Problem Solving Ability, Kvisoft Flipbook Maker

\section{PENDAHULUAN}

Pendidikan memiliki peran yang sangat penting karena dapat meningkatkan kualitas hidup manusia dan dapat mengembangkan potensinya, sehingga dapat memenuhi kebutuhan hidupnya sendiri (Diani, 2016). Pendidikan menengah bertujuan meningkatkan pengetahuan, kecerdasan, akhlak mulia, kepribadian, serta keterampilan untuk mandiri dan meningkatkan perkembangan teknologi (Yuda, Suma, \& Candiasa, 2014).

Perkembangan teknologi ditandai dengan munculnya berbasis teknologi salah satunya e-education (Hamzah, 2011). Eeducation atau electronic-education dapat diartikan sebagai proses pendidikan yang memanfaatkan peralatan atau piranti elektronika (Wilyanto, Prasetijo, \& Soemantri, 
2011). SMA N 1 Purworejo adalah salah satu sekolah di kabupaten Purworejo yang menggunakan kurikulum 2013 dengan melaksanakan Sistem Kredit Semester (SKS) dan penerapan pembelajaran dengan mengunakan Unit Kegiatan Belajar Mandiri (UKBM). Melalui UKBM peserta didik harus mencapai ketuntasan secara individual terhadap keseluruhan Kompetensi Inti (KI) dan Kompetensi Dasar (KD) matapelajaran dalam pelaksanaan layanan utuh (Kemendikbud, 2016).

Berdasarkan hasil dari observasi pengamatan penilaian ulangan harian yang sesuai dengan indikator problem solving dalam soal, diperoleh informasi yakni dalam pembelajaran fisika $80,0 \%$ peserta didik tuntas dalam penilaian ulangan harian dan $20,0 \%$ peserta didik belum tuntas dalam penilaian ulangan harian sehingga dalam penyelesaian problem solving masih perlu ditingkatkan. Sumber belajar menggunakan buku paket, tetapi tidak semua siswa mempunyai buku paket. Sumber lainnya yaitu LKS dan UKBM. Proses pembelajaran fisika masih menggunakan metode ceramah untuk penggunaan teknologi informasi dalam pembelajaran seperti powerpoint belum sepenuhnya maksimal.

Konsep pemahaman materi yang diajarkan agar dapat dipahami secara utuh dan dapat menggunakan di kehidupan nyata juga masih menjadi masalah yang mendasar. Bagaimana guru dapat berkomunikasi dengan baik dengan peserta didik, bagaimana guru dapat membuka wawasan berpikir peserta didik dengan latar belakang yang beragam sehingga dapat mempelajari berbagai konsep dan cara mengaitkannya serta memecahkan masalah. Karena kualitas proses yang baik akan menghasilkan prestasi belajar yang baik (Nurhidayati, 2019). Upaya memperbaiki proses pembelajaran untuk menyelesaikan persoalan itu adalah dengan menerapkan pembelajaran berbasis pemecahan masalah (problem solving). Problem solving adalah suatu cara menyajikan pelajaran dengan mendorong siswa untuk mencari atau memecahkan masalah dalam rangka pencapaian tujuan pengajaran (Sopia,
Sugiatno, \& Hartoyo, 2019).

Pemaparan di atas dilakukan penelitan mengembangkan sistem Unit Kegiatan Belajar Mandiri (UKBM) berbasis e-learning sebagai pengembangan bahan ajar melalui media pembelajaran interaktif yang bertujuan meningkatkan kemampuan problem solving peserta didik, guna memanfaatkan teknologi maka digunakan media pembelajaran $e$ learning dan untuk meningkatkan pembelajaran supaya lebih bervariatif. Banyak aplikasi untuk mengembangkan konten multimedia interaktif seperti saat ini di antaranya adalah kvisoft flipbook maker, aplikasi ini tidak terpaku hanya pada tulisan-tulisan saja tetapi bisa dimasukan sebuah animasi gerak, video, dan audio yang bisa menjadikan sebuah interaktif media pembelajaran yang menarik sehingga pembelajaran tidak monoton (Wibowo \& Pratiwi, 2018).

Berdasarkan berbagai uraian permasalahan tersebut maka peneliti tertarik untuk melakukan penelitian tentang E-UKBM dengan aplikasi kvisoft flipbook maker dalam pembelajaran fisika untuk meningkatkan kemampuan problem solving peserta didik di SMA N 1 Purworejo. Sejalan dengan penelitian yang dilakukan Ghofur A (2015) tentang pengembangan e-book berbasis flash kvisoft flipbook maker pada materi kinematika gerak lurus sebagai sarana belajar siswa SMA kelas $\mathrm{X}$.

\section{METODE/EKSPERIMEN}

Desain penelitian ini adalah Research and Development (R\&D) yang diadaptasi dari model penelitian Plomp (1997) yang terdiri dari lima fase yaitu: (1) Investigasi, (2) Perancangan, (3) Realisasi/Konstruksi, (4) Tes, Evaluasi, dan Revisi, (5) Penerapan (Widiana, 2016). Fase Investigasi (Preliminary Investigation) memiliki tujuan mengumpulkan data-data atau informasi yang terdapat di sekolah, kegiatan ini dilakukan analisis awalakhir dan analisis materi. Fase Perancangan (Design) meliputi pemilihan media dan pemilihan format untuk mendesain atau 
merancang isi pembelajaran, pemilihan strategi pembelajaran, dan sumber belajar yang sesuai. Fase

Realisasi/Konstruksi (Realization/Contruction) bertujuan untuk merealisasikan desain yang telah dirancang. Fase Tes, Evaluasi, dan Revisi (Test, Evaluation, and Revision) memiliki tujuan untuk menilai kevalidan produk pengembangan. Fase Penerapan (Implementasi) diterapkan untuk mengetahui keterlaksanaan pembelajaran sehingga menghasilkan E-UKBM yang layak (valid, praktis, dan efektif).

Teknik analisis data meliputi analisis data validitas (validitas RPP, validitas E-UKBM, validitas E-Modul, validitas LKS, validitas tes problem solving, validitas keterlaksanaan RPP, validitas aktivitas peserta didik, dan validitas respon peserta didik). Data yang diperoleh dari validator kemudian dihitung seperti persamaan 1 (Akhdinirwanto, 2018).

$$
\bar{x}=\frac{\sum f m}{\sum f a}
$$

Keterangan:

$$
\begin{array}{ll}
\bar{x} & =\text { Skor rata-rata } \\
\sum f m & =\text { Jumlah frekuensi yang muncul } \\
\sum f a & =\text { Jumlah seluruh frekuensi }
\end{array}
$$

Setelah ini diperoleh, selanjutnya menentukan kategori kevalidan sesuai dalam Tabel 1 agar dapat diketahui kevalidan produk (Hanifa, Wulandari, \& Sastika, 2019).

Tabel 1. Kriteria Kevalidan Produk

\begin{tabular}{ccc}
\hline No & Interval Skor & Kriteria \\
\hline 1 & $\bar{x}>3,25$ & Sangat Valid \\
2 & $2,5<\bar{x} \leq 3,25$ & Valid \\
3 & $1,75<\bar{x} \leq 2,5$ & Kurang Valid \\
4 & $\bar{x} \leq 1,75$ & Tidak Valid \\
\hline
\end{tabular}

Selanjutnya melakukan uji reliabilitas mennggunakan persamaan 2 Presentage of Agreement (PA) sebagai berikut.

$$
P A=\left(1-\frac{A-B}{A+B}\right) \times 100 \%
$$

Keterangan:

$$
\begin{aligned}
& P A \quad=\text { Presentage Agreement } \\
& A \quad=\text { Skor tertinggi dari pengamat } \\
& B \quad=\text { Skor terendah dari pengamat } \\
& \text { Instrumen yang diterapkan dikatakan } \\
& \text { reliabel jika mempunyai presentasi } \geq 75 \% \\
& \text { (Akhdinirwanto, 2018). }
\end{aligned}
$$

Setelah data reliabel diperoleh selanjutnya menghitung kepraktisan produk, dengan menganalisis data keterlaksanaan RPP oleh dua observer menggunakan persamaan 2 Precentage of Agreement.

Analisis data keefektifan dengan tes kemampuan problem solving dengan menggunakan $\mathrm{N}$-Gain pre-test dan post-test setiap pertemuan dengan indikator soal problem solving menurut Newman yaitu: (1) Membaca (Reading), (2) Memahami (Comprehension), (3) Transformasi (Transformation), (4) Keterampilan Proses (Process Skill), (5) Encoding. Langkah membaca (reading) meliputi siswa diminta membaca pertanyaannya, langkah memahami (comprehension) siswa dapat memahami apa saja yang diketahui soal dan apa yang ditanyakan dari soal yang diberikan, langkah transformsi (transformasi) siswa dapat mengetahui metode/memilih rumus yang tepat untuk menyelesaikan soal, keterampilan proses (process skill) meliputi siswa dapat mengetahui langkah-langkah yang akan digunakan untuk menyelesikan soal, encoding meliputi siswa mampu memberikan jawaban dari soal yang diberikan (Jha, 2012; Singh, 2010). Hake (1998) menyatakan $N$-Gain dapat dicari menggunakan persamaan 3 (Akhdinirwanto, 2018).

$$
g=\frac{s f-s i}{100-s i}
$$

Keterangan:

$$
\begin{array}{ll}
g & =\text { Gain } \\
s f & =\text { Nilai post-test } \\
s i & =\text { Nilai pre-test }
\end{array}
$$

Hasil dari perhitungan ini kemudian dikonversikan ke dalam kriteria kemampuan problem solving berdasarkan ketentuan sebagaimana ditunjukan pada Tabel 2.

Tabel 2. Kriteria $N$-Gain

\begin{tabular}{ccc}
\hline No & Tingkat Presentase (\%) & Kriteria \\
\hline 1 & $g \geq 0,7$ & Tinggi \\
2 & $0,3 \geq g>0,7$ & Sedang \\
3 & $g<0,3$ & Rendah \\
\hline
\end{tabular}

Hasil pre-test dan post-test kemudian dianalisis menggunakan uji normalitas dan uji paired samples t-test berpasangan untuk menguji apakah ada atau tidak perbedaan setelah melaksanakan pembelajaran 
menggunakan E-UKBM dengan aplikasi kvisoft flipbook maker.

Langkah selanjutnya menghitung aktivitas peserta didik ole kedua observer yang dihitung menggunakan Precentage Of Agreement (PA) persamaan 2.

Analisis selanjutnya respon peserta didik menggunkan persamaan 4 (Akhdinirwanto, 2018)

$$
P \%=\frac{\sum R}{\sum N} \times 100 \%
$$

Keterangan:

$P \quad=$ Nilai persen yang dicari

$R \quad=$ Nilai yang diperoleh

$N \quad=$ Nilai maksimum ideal

Hasil percentage ini diubah ke dalam bentuk kriteria analisis sesuai dengan acuan Tabel 3.

Tabel 3. Acuan Analisis Presentase

\begin{tabular}{ccc}
\hline No & Tingkat Presentase (\%) & Kriteria \\
\hline 1 & $80-100$ & Sangat Baik \\
2 & $60-80$ & Baik \\
3 & $40-60$ & Kurang Baik \\
4 & $\leq 40$ & Tidak Baik \\
\hline
\end{tabular}

\section{HASIL DAN PEMBAHASAN}

Perangkat pembelajaran yang dinilai ialah RPP, E-UKBM, E-Modul, LKS, tes kemampuan problem solving, keterlaksanaan RPP, aktivitas peserta didik, dan lembar respon peserta didik. Pengembangan E-UKBM ini mendapatkan hasil bahwa setiap komponen termasuk dalam kategori valid dan sangat baik digunakan. Hasil ini menunjukan bahwa pengembangan EUKBM dengan aplikasi kvisoft flipbook maker dalam pembelajaran fisika untuk meningkatkan kemampuan problem solving memberikan peluang untuk diterapkan di sekolah.

Tabel 4. Hasil Validasi RPP

\begin{tabular}{ccc}
\hline No & Aspek yang dinilai & Reliabilitas \\
\hline 1 & Tujuan & $100,0 \%$ \\
2 & Isi & $100,0 \%$ \\
3 & Bahasa & $92,4 \%$ \\
4 & Waktu & $86,0 \%$ \\
Jumlah skor aktual & $\mathbf{9 8 , 7 \%}$ \\
\hline
\end{tabular}

Berdasarkan data tersebut, klasifikasi RPP yang tercantum dalam tabel dapat disimpulkan bahwa RPP sangat baik digunakan dalam presentase $98,7 \%$. Sesuai dengan penelitian Miftachul Khoiriah (2020) yang menyatakan hasil validasi RPP sangat valid sesuai dengan sintaks kurikulum 2013, kesesuaian pemilihan pendekatan dengan tujuan pembelajaran kejelasan rincian waktu dan tahapan pembelajaran, serta penggunaan bahasa yang baik dan benar.

Tabel 5. Hasil Validasi E-UKBM

\begin{tabular}{ccc}
\hline No & Aspek yang dinilai & Reliabilitas \\
\hline 1 & Manfaat & $100,0 \%$ \\
2 & Bahasa & $94,2 \%$ \\
3 & Isi & $97,0 \%$ \\
4 & Desain & $95,0 \%$ \\
5 & Sajian & $100,0 \%$ \\
Jumlah skor aktual & $\mathbf{9 5 , 9 \%}$ \\
\hline
\end{tabular}

Dari tabel 5 hasil validasi E-UKBM dapat disimpulkan bahwa presentase secara keseluruhan sebesar 95,9\% dengan kategori sangat baik digunakan. Senada dengan penelitian Untari Lisya Kurniawati (2019) yang menyatakan pengelolaan pembelajaran menggunakan UKBM mendapat kategori baik.

Tabel 6. Hasil Validasi E-Modul

\begin{tabular}{ccc}
\hline No & Aspek yang dinilai & Reliabilitas \\
\hline 1 & Manfaat & $100,0 \%$ \\
2 & Bahasa & $94,2 \%$ \\
3 & Isi & $100,0 \%$ \\
4 & Desain & $100,0 \%$ \\
5 & Sajian & $86,0 \%$ \\
Jumlah skor aktual & $\mathbf{9 6 , 3} \%$ \\
\hline
\end{tabular}

Berdasarkan hasil validasi E-Modul, klasifikasi E-Modul yang tercatum dalam tabel dapat disimpulkan bahwa E-Modul sangat baik digunakan dengan presentase sebesar $96,3 \%$. Sejalan dengan penelitian Nana Nurjannati (2017) yang menyatakan E-Modul sangat layak digunakan dalam pembelajaran berdasarkan hasil validasi dosen ahli.

Tabel 7. Hasil Validasi LKS

\begin{tabular}{ccc}
\hline No & Aspek yang dinilai & Reliabilitas \\
\hline 1 & Manfaat & $86,0 \%$ \\
2 & Bahasa & $97,2 \%$ \\
3 & Isi & $100,0 \%$ \\
4 & Desain & $100,0 \%$ \\
Jumlah skor aktual & $\mathbf{9 7 , 5 \%}$ \\
\hline
\end{tabular}

Data hasil validasi LKS menunjukan skor presentase akhir sebesar $97,5 \%$ yang termasuk dalam kategori sangat baik digunakan. Senada dengan penelitian Y. Astuti 
(2013) yang menyatakan hasil validitas LKS pengembangan berkategori baik sehingga dikatakan layak dan efektif yang sebelumnya sudah dilakukan revisi-revisi sesuai saran validator untuk meningkatkan kualitas perangkat pembelajaran.

Tabel 8. Hasil Validasi Tes Kemampuan Problem Solving

\begin{tabular}{ccc}
\hline No & Aspek yang dinilai & Reliabilitas \\
\hline 1 & Konstruksi & $93,4 \%$ \\
2 & Isi & $94,5 \%$ \\
3 & Bahasa & $95,3 \%$ \\
4 & Waktu & $100,0 \%$ \\
Jumlah skor aktual & $\mathbf{9 6 , 8 \%}$ \\
\hline
\end{tabular}

Berdasarkan Tabel 8 hasil validasi tes kemampuan problem solving diperoleh skor akhir 96,8\% termasuk dalam kategori sangat baik digunakan. Senada dengan penelitian Nutia Rahmatin (2019) yang menyatakan hasil validasi pemecahan masalah tiap aspek mendapat penilaian baik, termasuk kategori sangat valid.

Tabel 9. Hasil Validasi Keterlaksanaan RPP

\begin{tabular}{ccc}
\hline No & Aspek yang dinilai & Reliabilitas \\
\hline 1 & Kebahasaan & $100,0 \%$ \\
2 & Sajian & $95,3 \%$ \\
3 & Desain & $100,0 \%$ \\
Jumlah skor aktual & $\mathbf{9 7 , 6 \%}$ \\
\hline
\end{tabular}

Tabel 9 menunjukan hasil dari validasi keterlaksanaan RPP dengan skor akhir 97,6\% termasuk dalam kategori sangat baik digunakan. Sejalan dengan penelitian Agustina Fatmawati (2016) yang menyatakan keterlaksanaan RPP tergolong sangat baik dengan nilai $>3,5$ penilaian yang dilakukan oleh validator dalam perangkat pembelajaran.

Tabel 10. Hasil Validasi Aktivitas Peserta Didik

\begin{tabular}{ccc}
\hline No & Aspek yang dinilai & Reliabilitas \\
\hline 1 & Kebahasaan & $92,3 \%$ \\
2 & Sajian & $95,3 \%$ \\
3 & Desain & $85,8 \%$ \\
Jumlah skor aktual & $\mathbf{9 2 , 7 \%}$ \\
\hline
\end{tabular}

Dari Tabel 10 hasil validasi aktivitas peserta didik mempunyai rata-rata reliabilitas $92,7 \%$ yang termasuk dalam kategori sangat baik digunakan. Sejalan dengan penelitian Nur Fitria Rachmayanti (2019) yang menyatakan aktivitas peserta didik sebesar $92,7 \%$ dengan ketegori sangat valid sesuai penilaian validator dalam pengembangan modul biologi.

Tabel 11. Hasil Validasi Respon Peserta Didik

\begin{tabular}{ccc}
\hline No & Aspek yang dinilai & Reliabilitas \\
\hline 1 & Kebahasaan & $92,3 \%$ \\
2 & Sajian & $95,3 \%$ \\
3 & Desain & $100,0 \%$ \\
Jumlah skor aktual & $\mathbf{9 5 , 0 \%}$ \\
\hline
\end{tabular}

Tabel 11 hasil validasi respon peserta didik mempunyai rata-rata reliabilitas sebesar $95,0 \%$ yang termasuk dalam kategori sangat baik digunakan. Sejalan dengan penelitian Didik Purwanto (2013) yang menyatkan respon peserta didik sebesar $92,7 \%$ dengan kategori sangat layak dalam penelitian mengenai pengembangan komik IPA Terpadu.

Setelah dilakukan uji validitas, dan dapat dilihat bahwa lembar validasi RPP, lembar validasi E-UKBM, lembar validasi EModul, lembar validasi LKS, lembar validasi Tes Kemampuan Problem Solving, lembar validasi Keterlaksanaan RPP, lembar validasi Aktivitas Peserta Didik, dan lembar validasi Respon peserta didik dinyatakan dengan kriteria sangat valid oleh validator.

Lembar validasi dikatakan valid artinya perangkat pembelajaran yang dikembangkan menjalankan fungsi ukurnya atau memberikan hasil ukur sesuai dengan maksud dilakukan pengukuran tersebut (Putra, 2013).

Kepraktisan dapat dilihat dari hasil uji Keterlaksanaan RPP oleh dua observer Tabel 12.

Tabel 12. Hasil Keterlaksanaan RPP

\begin{tabular}{ccc}
\hline No & Pertemuan & Skor aktual \\
\hline 1 & Pertemuan I & $95,9 \%$ \\
2 & Pertemuan II & $100,0 \%$ \\
3 & Pertemuan III & $98,8 \%$ \\
\hline
\end{tabular}

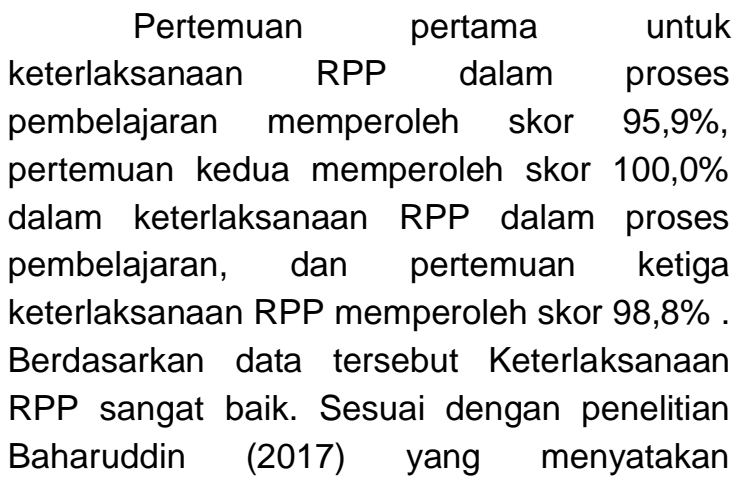


keterlaksanaan RPP dalam kategori baik, pertemuan pertama dengan presentase $95,0 \%$, pertemuan kedua dengan presentase sebesar $100,0 \%$, dan pertemuan ketiga $95,0 \%$ yang dinilai observer selama pengambilan data perangkat pembelajaran IPA.

Hasil keefektifan peserta didik di peroleh dari tes kemampuan peserta didik, aktivitas peserta didik, dan respon peserta didik. Capaian $\mathrm{N}$-Gain pada tes kemampuan problem solving sebanyak tiga kali pertemuan pada Tabel 13.

Tabel 13. N-Gain Pre-Test dan Post-Test

\begin{tabular}{ccc}
\hline Pre-Test & Post-Test & N-Gain \\
\hline 68,26 & 79,97 & 0,45 \\
65,90 & 85,00 & 0,56 \\
65,97 & 86,87 & 0,61 \\
\hline
\end{tabular}

Tabel 13 menunjukan nilai pre-test pada pertemuan pertama sebesar 68,26 dan nilai post-test sebesar 79,97 dengan nilai $N$ Gain 0,45 dengan kategori sedang, pertemuan kedua nilai pre-test sebesar 65,90 dan nilai post-test sebesar 85,00 nilai $N$-Gain sebesar 0,56 kategori sedang. Pertemuan ketiga memperoleh nilai pre-test 65,97 dan nilai posttest 86,87 dengan $\mathrm{N}$-Gain 0,61 dengan kategori sedang sesuai acuan kriteria $N$-Gain. Senada dengan penelitian Ikhwan Khairu Sadiqin (2017) yang menyatakan hasil pre-test dan post-test soal problem solving mengalami peningkatan $\mathrm{N}$-Gain sedang sebesar 0,479 peningkatan pre-test dan post-test dipicu oleh perkembangan menalar siswa yang sesuai dengan indikator problem solving.

\section{Capaian indikator Kemampuan} Problem Solving sesuai indikator Newman pada penelitian ini seperti pada Gambar 1.

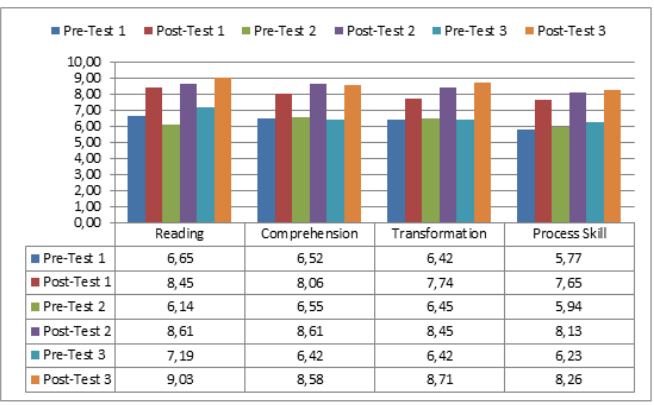

Gambar 1. Presentase jawaban pre-test dan post-test

Berdasarkan hasil pertemuan pertama untuk kelas X MIA 3 skor jawaban benar pretest untuk indikator reading sebesar $6,65 \%$, comprehension sebesar $6,52 \%$, transformation $6,42 \%$, dan process skill sebesar $5,77 \%$. Sedangkan post-test pertemuan pertama untuk kelas X MIA 3 skor jawaban benar untuk indikator reading sebesar $8,45 \%$, comprehension sebesar $8,06 \%$, transformation sebesar $7,74 \%$, dan process skill $7,65 \%$.

Hasil pre-test pertemuan kedua untuk kelas X MIA 3 skor jawaban benar untuk indikator reading sebesar $6,14 \%$, comprehension sebesar $6,55 \%$, transformation sebesar 6,45\%, dan process skill 5,94\%. Sedang post-test pertemuan kedua untuk kelas $X$ MIA 3 jawaban benar indikator reading $8,61 \%$, comprehension sebesar $8,61 \%$, transformation sebesar $8,45 \%$, dan process skill $8,13 \%$.

Pertemuan ketiga untuk kelas X MIA 3 jawaban benar untuk indikator reading sebesar $7,19 \%$, comprehension sebesar $6,42 \%$, dan transformation sebesar $6,42 \%$, dan process skill sebesar $6,23 \%$. Sedangkan pada post-test pertemuan ketiga untuk kelas X MIA 3 jawaban benar untuk indikator reading sebesar $9,03 \%$, comprehension sebesar $8,58 \%$, transformation sebesar $8,71 \%$, dan process skill 8,26\%. Dari gambar 1 dapat disimpulkan untuk hasil pretest setiap indikator dari pertemuan pertama sampai pertemuan ketiga mengalami peningkatan dalam hasil post-test setiap indikatornya. Selanjutnya dilakukan uji Normalitas menggunakan uji Kolmogorov.

Tabel 14. Hasil Uji Kolmogorov

\begin{tabular}{ccc}
\hline Tes & $\begin{array}{c}\text { Asymp.Sig. (2- } \\
\text { tailed) }\end{array}$ & $\begin{array}{c}\text { Distribusi } \\
\text { Normal }\end{array}$ \\
\hline Pre-test 1 & 0,102 & Normal \\
Post-test 1 & 0,176 & Normal \\
Pre-test 2 & 0,060 & Normal \\
Post-test 2 & 0,061 & Normal \\
Pre-test 3 & 0,108 & Normal \\
Post-test 3 & 0,063 & Normal \\
\hline
\end{tabular}

Tabel 14 menunjukan uji normalitas Kolmogorov dengan ketentuan hasil Asymp.Sig. (2-tailed) lebih besar dari 0,05 (Silaban, 2014). Pre-test 1 Asymp.Sig. (2tailed) sebesar 0,102 > 0,05 maka berdistribusi 
normal. Post-test 1 Asymp.Sig. (2-tailed) sebesar $0,176>0,05$ maka berdistribusi normal. Pre-test 2 Asymp.Sig. (2-tailed) sebesar $0,060>0,05$ maka berdistribusi normal. Post-test 2 Asymp.Sig (2-tailed) sebesar $0,061>0,05$ maka berdistribusi normal. Pre-test 3 Asymp.Sig. (2-tailed) 0,108 $>0,05$ maka berdistribusi normal. Post-test Asymp.Sig. (2-tailed) 0,063>0,05 maka berdistribusi normal. Setelah dilakukan uji normalitas selanjutnya melakukan uji paired $t$ test. Seperti pada tabel 15.

Tabel 15. Hasil Uji Kolmogorov

\begin{tabular}{ccc}
\hline Tes & Mean & Sig. (2-tailed) \\
\hline Pre-test 1 \& Post-test 1 & $-16,710$ & 0,000 \\
Pre-test 2 \& Post-test 2 & $-19,097$ & 0,000 \\
Pre-test 3 \& Post-test 3 & $-20,903$ & 0,000 \\
\hline
\end{tabular}

Pengujian yang digunakan adalah jika $p$ (signifikansi) $>0,05$ maka hipotesis nihil $(\mathrm{Ho})$ diterima dan hipotesis alternatif $(\mathrm{Ha})$ ditolak, jika $\mathrm{p}$ (signifikansi) $\leq 0,05$ maka hipotesis nihil $(\mathrm{Ho})$ ditolak dan hipotesis alternatif $(\mathrm{Ha})$ diterima (Fikriyah \& Gani, 2015). Pada pertemuan pertama sampai pertemuan ketiga dimana nilai Sig. (2-tailed) 0,000 $<0,005$ maka $\mathrm{Ho}$ diterima dan $\mathrm{Ha}$ ditolak sehingga dapat disimpulkan ada perbedaan antara nilai pre-test dan nilai post-test.

Selanjutnya hasil penilaian aktivitas peserta didik selama tiga kali pertemuan seperti pada Tabel 16 sampai Tabel 18.

\begin{tabular}{|c|c|c|}
\hline No & Aspek yang diamati & Reliabilitas \\
\hline 1 & $\begin{array}{l}\text { Mendengarkan dan } \\
\text { memperhatikan }\end{array}$ & $100,0 \%$ \\
\hline 2 & $\begin{array}{l}\text { Mengajukan, menjawab, dan } \\
\text { menanggapi }\end{array}$ & $100,0 \%$ \\
\hline 3 & Bekerja sama & $85,8 \%$ \\
\hline 4 & $\begin{array}{l}\text { Memahami dan } \\
\text { menyelesaikan soal }\end{array}$ & $100,0 \%$ \\
\hline 5 & Kemampuan problem solving & $85,8 \%$ \\
\hline 6 & Menyimpulkan & $100.0 \%$ \\
\hline 7 & Menghormati & $85,8 \%$ \\
\hline 8 & Perilaku relevan & $100.0 \%$ \\
\hline \multicolumn{2}{|c|}{ Jumlah skor aktual } & $98.1 \%$ \\
\hline
\end{tabular}

Berdasarkan Tabel 16 aktivitas peserta didik pada pertemuan pertama diperoleh skor aktual $98,1 \%$ yang meliputi aspek mendengarkan dan memperhatikan secara umum pada saat pembelajaran sebesar
$100,0 \%$, aspek mengajukan, menjawab, dan menanggapi sebesar $100,0 \%$, aspek bekerja sama sebesar $85,8 \%$, aspek memahami dan menyelesaikan soal sebesar $100,0 \%$, aspek kemampuan problem solving peserta didik pada saat menyelesaikan latihan soal $85,8 \%$, aspek menyimpulkan sebesar $100,0 \%$, aspek menghormati sebesar $85,8 \%$, dan aspek perilaku relevan saat pebelajaran berlangsung sebesar $100,0 \%$.

Tabel 17. Aktivitas Peserta Didik Pertemuan II

\begin{tabular}{clc}
\hline No & \multicolumn{1}{c}{ Aspek yang diamati } & Reliabilitas \\
\hline 1 & Mendengarkan dan & $100,0 \%$ \\
2 & $\begin{array}{l}\text { memperhatikan } \\
\text { Mengajukan, menjawab, dan }\end{array}$ & $100,0 \%$ \\
& menanggapi & $100,0 \%$ \\
3 & Bekerja sama & $85,8 \%$ \\
& Memahami dan & $100,0 \%$ \\
5 & menyelesaikan soal & $100,0 \%$ \\
6 & Memampuan problem solving \\
7 & Menghormati & $100,0 \%$ \\
Jumlah skor aktual & $100,0 \%$ \\
\hline & & $\mathbf{9 8 , 1 \%}$ \\
\hline
\end{tabular}

Hasil pemaparan pada Tabel 17 pada pertemuan ke II skor aktual sebesar 98,1\% meliputi aspek mendengarkan dan memperhatikan yang dilihat secara umum saat pembelajaran berlangsung sebesar 100,0\%, aspek mengajukan, menjawab, dan menanggapi sebesar $100,0 \%$, aspek bekerja sama yang dilihat secara umum sebesar $100,0 \%$, aspek memahami dan menyelesaikan soal sebesar $100,0 \%$, aspek kemampuan problem solving peserta didik sebesar $85,8 \%$. Aspek menyimpulkan sebesar $100,0 \%$, aspek menghormati sebesar $85,8 \%$ dan aspek perilaku relevan pada saat pembelajaran sebesar $100,0 \%$.

Tabel 18. Aktivitas Peserta Didik Pertemuan III

\begin{tabular}{|c|c|c|}
\hline No & Aspek yang diamati & Reliabilitas \\
\hline 1 & $\begin{array}{l}\text { Mendengarkan dan } \\
\text { memperhatikan }\end{array}$ & $100,0 \%$ \\
\hline 2 & $\begin{array}{l}\text { Mengajukan, menjawab, dan } \\
\text { menanggapi }\end{array}$ & $100,0 \%$ \\
\hline 3 & Bekerja sama & $100,0 \%$ \\
\hline 4 & $\begin{array}{l}\text { Memahami dan } \\
\text { menyelesaikan soal }\end{array}$ & $100,0 \%$ \\
\hline 5 & Kemampuan problem solving & $100,0 \%$ \\
\hline 6 & Menyimpulkan & $100,0 \%$ \\
\hline 7 & Menghormati & $85,8 \%$ \\
\hline 8 & Perilaku relevan & $100,0 \%$ \\
\hline \multicolumn{2}{|c|}{ Jumlah skor aktual } & $98,2 \%$ \\
\hline
\end{tabular}


Berdasarkan hasil pemaparan Tabel 18 pertemuan ketiga aktivitas peserta didik secara umum diperoleh skor aktual 98,2\% meliputi aspek mendengarkan dan memperhatikan 100,0\%, aspek mengajukan, menjawab, dan menanggapi secara umum sebesar $100,0 \%$, aspek bekerja sama $100,0 \%$, aspek memahami dan menyelesaikan soal $100,0 \%$, aspek kemampuan problem solving $100,0 \%$, aspek menyimpulkan $100,0 \%$, aspek menghormati $85,8 \%$, dan aspek perilaku relevan $100,0 \%$. Senada dengan penelitian Syofnidah Ifrianti (2016) yang menyatakan aktivitas peserta didik tiap pertemuan mengalami peningkatan sehingga media baik digunakan dalam pebelajaran. Respon peserta didik X MIA 3 dalam menggunakan E-UKBM dengan aplikasi kvisoft flipbook maker pada Tabel 19.

Tabel 19. Respon Peserta Didik

\begin{tabular}{ccc}
\hline No & Aspek & Persentase \\
\hline 1 & Penggunaan & $83,06 \%$ \\
2 & Kelayakan Isi & $88,51 \%$ \\
3 & Kebahasaan & $81,85 \%$ \\
4 & Desain & $83,06 \%$ \\
5 & Interaksi Media & $82,25 \%$ \\
Rerata & & $\mathbf{8 3 , 7 5 \%}$ \\
\hline
\end{tabular}

Data pada Tabel 19 menunjukan respon peserta didik kelas X MIA 3 terhadap EUKBM fisika dengan aplikasi kvisoft flipbook maker dari berbagai aspek termasuk dalam kategori sangat baik. Sesuai dengan penelitian Sri Latifah (2016) yang menyatakan bahwa respon peserta didik dalam penelitian pengembangan lembar kerja peserta didik sebesar $90,0 \%$ dengan sangat baik.

\section{PENUTUP}

Berdasarkan penelitian yang telah dilakukan dapat disimpulkan bahwa E-UKBM dengan aplikasi kvisoft flipbook maker dalam pembelajaran fisika untuk meningkatkan kemampuan problem solving peserta didik dalam kategori sangat valid. Simpulan tersebut berdasarkan beberapa hal yaitu, (1) E-UKBM fisika dengan aplikasi kvisoft flipbook maker sangat valid, (2) E-UKBM fisika dengan aplikasi kvisoft flipbook maker yang dikembangkan praktis karena dapat dilaksanakan dalam pembelajaran, (3) E-UKBM fisika dengan aplikasi kvisoft flipbook maker efektif untuk meningkatkan kemampuan problem solving, peserta didik melakukan aktivitas positif selama pembelajaran, dan peserta didik merespon sangat baik dalam pembelajaran.

\section{UCAPAN TERIMAKASIH}

Terimakasih kepada Bapak/lbu dosen Pendidikan Fisika Universitas Muhammadiyah Purworejo yang telah membantu proses validasi produk, terima kasih kepada Kepala Sekolah SMA N 1 Purworejo yang telah mengizinkan penelitian, dan terimakasih kepada peserta didik kelas X MIA 3 SMA N 1 Purworejo yang turut berpartisipasi dalam penelitian ini.

\section{REFERENSI}

Akhdinirwanto, R. W. (2018). Model Problem-Based Learning with Argumentation (PBLA) untuk Meningkatkan Keterampilan Berpikir Kritis Siswa SMP. (Disertasi, tidak diterbitkan). Surabaya: PPS Unesa

Astuti, Y., \& Setiawan, B. (2013). Pengembangan Lembar Kerja Siswa (LKS) Berbasis Pendekatan Inkuiri Terbimbing dalam Pembelajaran Kooperatif pada Materi Kalor. Jurnal Pendidikan IPA Indonesia, 2(1).

Baharuddin, B., Indana, S., \& Koestiari, T. (2017). Perangkat Pembelajaran IPA Berbasis Pendekatan Inkuiri Terbimbing dalam Pembelajaran Kooperatif pada Materi Kalor. Jurnal Pendidikan IPA Indonesia, 2(1).

Diani, R. (2016). Pengaruh Pendekatan Saintifik Berbentukan LKS Terhadap Hasil Belajar Fisika Peserta Didik Kelas XI SMA Perintis 1 Bandar Lampung. Jurnal IImiah Pendidikan Fisika Al-Biruni, 5(1), 83-93.

Fatmawati, A. (2016). Pengembangan Perangkat Pemelajaran Konsep Pencemaran Lingkungan Menggunakan Model 
Pembelajaran Berdasarkan Masalah Untuk SMA Kelas X. Edu Sains: Jurnal Pendidikan Sains dan Matematika, 4(2).

Fikriyah, M., \& Gani, A. A. (2015). Model Pembelajaran Berbasis Proyek (Project Based Learning) Disertai Media AudioVisual Dalam Pembelajaran Fisika Di SMAN 4 Jember. Jurnal Pembelajaran Fisika, 4(2).

Hanifa, F. H., Wulandari, A., \& Sastika, W. (2019). Direct Rating Method Untuk Mengukur Efektifitas Iklan Melalui Media Televisi (Studi Pada Iklan The Pucuk Harum). IkraIth Humaniora: Jurnal Sosial dan Humaniora, 3(2), 5.

Hamzah, N. L. (2011). Teknologi Komunikasi dan Informasi Pembelajaran. Jakarta: Bumi Aksara.

Ifrianti, S., \& Emilia, Y. (2016). Pemanfaatan Lingkungan Sekitar Sebagai Media Pembelajaran IPS untuk Meningkatkan Aktivitas dan Hasil Belajar Peserta Didik Kelas III MIN 10 Bandar Lampung. Terampil: Jurnal Pendidikan dan Pembelajaran Dasar, 3(2), 22-42.

Jha, S. K. (2012). Mathematics Performance of Primary School Student in Assam (India): An Analysis Using Newman Procedure. International Journal of Computer Applications in Engineering Sciences, 2(1), 17-21.

Kemendikbud. (2016). Tujuan Pembelajaran Jenjang Sekolah Menengah Atas. Jakarta: Kemendikbud.

Khoiriah, M., \& Kholiq, A. (2020). Validitas Perangkat Pembelajaran Fisika Berbantuan E-Book Literasi Sains pada Materi Fluida Dinamis. Inovasi Pendidikan Fisika, 9(1).

Kurniawati, U. L. (2019). Efektivitas Pelaksanaan UKBM (Unit Kegiatan Belajar Mandiri) pada Pembelajaran Matematika di Kabupaten Sidoarjo. (Doctoral Dissertation, UIN Sunan Ampel Surabaya).

Latifah, S. (2016). Pengembangan Lembar Kerja Peserta Didik (LKPD) Berorientasi Nilainilai Agama Islam melalui Pendekatan Inkuiri Terbimbing pada Materi Suhu dan Kalor. Jurnal IImiah Pendidikan Fisika AlBiruni, 5(1), 43-51.
Nurhidayati, N. (2019). Deskripsi Analisis Implementasi Model Pembelajaran Group Investigation (GI) Sebagai Penguatan Regulasi Diri Mahasiswa.

Nurjannati, N., Rahmad, M., \& Irianti, M. (2017). Pengembagan E-Modul Berbasis Literasi Sains pada Materi Radasi Elektromagnetik (Doctoral Dissertation, Riau University).

Purwanto, D. (2013). Pengembangan Media Komik IPA Terpadu Tema Pencemaran Air Sebagai Media Pembelajaran Untuk Siswa SMP Kelas VII. Pensa E-Jurnal: Pendidikan Sains, 1(01).

Putra, S. R. (2013). Desain Evaluasi Belajar Berbasis Kinerja. Yogyakarta: DIVA

Rachmayanti, N., \& Kuswanti, N. (2019). Pengembangan Modul Pembelajaran Berbasis Hybrid Learning pada Submateri Sistem Saraf Untuk Meningkatkan Hasil Belajar Siswa Kelas XI SMA. Bioedu, 8(1).

Rahmatin, N., Pramita, D., Sirajuddin, S., \& Mahsup, M. (2019). Pengembangan Modul Pembelajaran Bangun Ruang dengan Metode Creative Problem Solving (CPS) pada Siswa Kelas VIII SMP. JTAM (Jurnal Teori dan Aplikasi Matematika), 3(1), 27-33.

Sadiqin, I. K., Santoso, U. T., \& Sholahuddin, A. (2017). Pemahaman Konsep IPA Siswa SMP Melalui Pembelajaran Problem Solving pada Topik Perubahan Bendabenda di Sekitar Kita. Jurnal Inovasi Pendidikan IPA, 3(1), 52-62.

Singh, P., Rahman, A. A., \& Hoon, T. S. (2010). The Newman Procedure for Analyzing Primary Four Pupils Errors on Written Mathematical Tasks: A Malaysian Perspective. ProcediaSocial and Behavioral Sciences, 8, 264271.

Sopia, N., Sugiatno, S., \& Hartoyo, A. (2019). Pengembangan Pemahaman Konseptual dan Disposisi Matematis Siswa Melalui Penerapan Pendekatan Problem Solving di SMA. J-PiMat: Jurnal Pendidikan Matematika, 1(1), 11-20.

Wibowo, E., \& Pratiwi, D. D. (2018). Pengembangan Bahan Ajar Menggunakan Aplikasi Kvisoft Flipbook Maker Materi Himpunan. Desimal: Jurnal Matematika, 1(2), 147-156. 
Widiana, I. W. (2016). E-Modul Berorientasi Pemecahan Masalah Dalam Pembelajaran Statistik Inferensial. Prosiding Semnas Hasil Penelitian.

Willyanto, W., Prasetijo, A. B., \& Soemantri, M. (2011). Perancangan Aplikasi E-Education Berbasis Web Dengan Menggunakan Bahasa Pemrograman PHP (Doctoral dissertation, Jurusan Teknik Elektro Fakultas Teknik Undip). 